\title{
Iodine-A Potential Antioxidant and the Role of Iodine/Iodide in Health and Disease
}

\author{
Rudolf Winkler \\ Paracelsus Society of Balneology and lodine Research, Bad Hall, Austria \\ Email: office@paracelsus-badhall.at
}

Received 9 July 2015; accepted 21 November 2015; published 24 November 2015

Copyright (C) 2015 by author and Scientific Research Publishing Inc.

This work is licensed under the Creative Commons Attribution International License (CC BY). http://creativecommons.org/licenses/by/4.0/

(c) (i) Open Access

\begin{abstract}
In human physiology, iodine is primarily noted for its role in thyroid function and less so for its many extrathyroidal functions, particularly those based on its antioxidant properties. As $\mathrm{I}^{-}$it protects against free radicals and peroxides. This is seen in vitro in decreased depolymerization of hyaluronic acid and increased antioxidant status in human serum, and in vivo in increased antioxidant enzyme activities and decreases of malondialdehyde and peroxides. It could be shown or deduced that balneotherapeutic applications of iodine/iodide have a positive effect on cardiocirculatory diseases, respiratory disorders, some eye diseases (dry eye, cataract, age-related macular degeneration), and other degenerative diseases connected with increased oxidative stress that are also treated by balneotherapy.
\end{abstract}

Keywords

Iodine, Antioxidant, Balneotherapy, Free Radical Associated Diseases

\section{Introduction}

This review presents the most important results of some 50 years' research in the field of the extrathyroidal, nonhormonal, predominantly antioxidant effects of iodide and its role in defense mechanisms against a number of diseases that can be subsumed under "free radical diseases". Special attention is given to the therapeutic efficacy of cures with the natural iodine-rich waters applied in Bad Hall, Austria. Thematically these studies fall into two categories: 1) basic studies on iodine uptake, resorption, distribution in organs, and relevant biochemical reactions, and 2) in vitro and in vivo studies on the role of iodine in human diseases.

\section{Physico-Chemical Basis}

Iodine not only plays an essential role in thyroid function including production of its hormones, but also in other

How to cite this paper: Winkler, R. (2015) lodine-A Potential Antioxidant and the Role of lodine/lodide in Health and Disease. Natural Science, 7, 548-557. http://dx.doi.org/10.4236/ns.2015.712055 
organs and tissues. The disinfectant properties of tincture of iodine have long been known, and iodine-rich water has proven useful in treating degenerative and inflammatory diseases. One extrathyroidal and non-endocrinological function of iodine is as an antioxidant $\left(\mathrm{I}^{-}\right)$that is effective in combatting free radicals and peroxides according to the scheme:

$$
2 \mathrm{R}^{\bullet}+2 \mathrm{I}^{-} \rightarrow 2 \mathrm{R}:+\mathrm{I}_{2}, \mathrm{R}^{\bullet}=\text { e.g. } \mathrm{OH}(\text { hydroxyl radical })
$$

Or also in the case of reduction of hydrogenperoxide and peroxide:

$$
\mathrm{H}_{2} \mathrm{O}_{2}+2 \mathrm{I}^{-} \rightarrow \mathrm{H}_{2} \mathrm{O}+\mathrm{I}_{2}
$$

or against lipid peroxidation :

$$
\begin{aligned}
\mathrm{LOOH}+2 \mathrm{H}^{+}+2 \mathrm{I}^{-} & \rightarrow \mathrm{LOH}+\mathrm{H}_{2} \mathrm{O}+\mathrm{I}_{2} ; \\
\mathrm{I}_{2} & \rightarrow 2 \mathrm{I}^{-}
\end{aligned}
$$

This catalytic system is very efficient: The resultant elemental iodine $\left(I_{2}\right)$ can be reduced again, e.g. by thiols, or incorporated into organic compounds. $\mathrm{I}_{2}$ (molecular iodine) is an oxidant with well-known antiseptic and bactericidal effects. But under physiological conditions, via peroxidases, iodine in the form of iodide will act to intensify leukocytic defense mechanisms [1].

\section{Pharmacokinetic and Balneotherapeutic Aspects}

Extrathyroidal mechanisms depend on a certain level of iodine in the target organs. A rough survey of the iodine content (e.g. iodine in all its forms) in the human body shows that about half of the iodine (6 - $14 \mathrm{mg}$ ) is concentrated in the thyroid, depending on its functional state; most of the rest is in connective tissues as well as in the skin and vascular walls. Some other tissues and organs have a special active transport mechanism, the NaI symporter, to concentrate iodine. There is active transport not only in the thyroid, but also in the stomach, salivary glands, lacrimal glands, ciliary body, choroid plexus and the lactating mamma. In the blood, half of the total iodine is bound in the thyroid hormone T4, with maximally $10 \%$ in T3 and in protein bound iodine (PBI); the erythrocytes contain only very little iodine [2] [3].

The level of inorganic iodine (mainly $\mathrm{I}^{-}$) is of great interest: it is highly variable and depends on iodine uptake, especially during drinking cures with iodine containing waters. Animal experiments have shown as much as a 40 -fold increase in the iodine level shortly after consumption, without significant change in hormone (T3, T4) levels [4]. This increase reaches its maximum after just $35 \mathrm{~min}$ and returns to baseline after 24 - $48 \mathrm{hrs}$. Balneotherapeutic treatments with iodine applications produce a manifold increase in iodine up take, measured as iodine excretion per g creatinine (Table 1).

\section{Iodine Balance (Intake-Distribution-Excretion)}

The daily iodine requirement for humans is about 150 to maximally $300 \mu \mathrm{g}$ and is essential for normal thyroid

\begin{tabular}{|c|c|}
\hline & $\mu \mathrm{g} / \mathrm{g}$ creatinine \\
\hline Drinking cures & up to 2500 \\
\hline Ocular Iontophoresis & 530 \\
\hline Baths & 350 \\
\hline Combined cures & 870 \\
\hline
\end{tabular}
function. In Austria, the most important source of iodine is nutritional salt with $20 \mathrm{mg} \mathrm{KI} / \mathrm{kg} \mathrm{NaCl}$. Daily consumption of 4 - $5 \mathrm{~g}$ salt provides 60 - $80 \mu \mathrm{g}$ iodine. This supply has to be complemented by iodine rich foods, especially sea fish and dairy products. 
More iodine is taken up through balneotherapeutic applications such as drinking cures (2 - $20 \mathrm{mg} / \mathrm{day}$, see section 3) and by iodide iontophoresis. The quantities of iodine waters recommended for daily consumption during a cure are limited by their sodium chloride content due to its harmful effects on thyroid and other physiological functions, and the daily supply now varies from $13 \mathrm{mg}$ down to $800 \mu \mathrm{g}$ [5].

Intact skin resorbs only a small amount of iodine in a bath (about $70 \mu$ g per iodine bath), but by the subsequent resorption through the skin it is many times higher, especially in the form of the elemental iodine $\left(\mathrm{I}_{2}\right)$.

The cornea of the eye takes up iodine applied in a spray. The sclera, chamber fluid and vitreous body also take up fair quantities of iodine, but little is taken up the by retina and lens. Higher I'uptake is obtained through ocular iontophoresis as applied therapeutically in Bad Hall (see Section 9).

The respiratory system takes up iodine well from electro-aerosol application. Administered orally, iodine is first taken up in the gastro-intestinal tract (especially by the gastric mucosa) and then distributed predominantly in the extracellular space, partially in the form of iodinated amino acids. According to their affinity for iodide, individual tissues and organs absorb more or less iodine. Animal experiments distinguished three groups of organs and tissues with respect to iodine absorption [3]:

1) Organs with active iodine transport (NaI-symporter system): primarily the thyroid (about 20 - 40-fold concentration), stomach, skin, eye (ciliary body), choroid plexus in the brain;

2) Organs without active transport: e.g. muscles and fatty tissue, and

3) Tissues with a high affinity for iodine but without active transport: predominantly connective tissue structures like tendons and blood vessels. Without this affinity, balneotherapy will be ineffective.

Iodine is mainly excreted via the kidney, normally $73-131 \mu \mathrm{g} / \mathrm{g}$ creatinine per day. (The relation to creatinine excretion is a good measure for iodine uptake). Comparatively little iodine is excreted through the faeces, bile fluid, sweat and lacrimal fluid.

\section{Antioxidant and Antiradical Effects}

Iodide $\left(\mathrm{I}^{-}\right)$can act as electron donor and consequently be effective as antioxidant and scavenger of free radicals according to the reaction Equation 5 and Figure 1.

$$
\mathrm{R}^{\bullet}+\mathrm{I}^{-} \rightarrow \mathrm{R}:+\mathrm{I}
$$

$\mathrm{R}$ usually represents the aggressive hydroxyl radical $\mathrm{OH}^{*}$. In this reaction the extremely tissue-toxic $\mathrm{OH}^{\circ}$ is scavenged and transformed into a harmless $\mathrm{OH}^{-}$(hydroxyl ion).

The antioxidative reaction can also be directed against $\mathrm{H}_{2} \mathrm{O}_{2}$ and other peroxides, including lipid peroxides. The emerging iodine radical is immediately converted to molecular iodine $\left(2 \mathrm{I}^{*} \rightarrow \mathrm{I}_{2}\right.$ ) and can be effective as an oxidant or can be reduced to iodide by the relatively alkaline environment of the body; it can also be incorporated into organic compounds. The oxidizing property of $\mathrm{I}_{2}$ can be seen in its antiseptic and bactericidal effect. Under physiological conditions, iodine or iodide work predominantly via enzymatic reactions, especially the peroxidase reaction. Iodine can have an enhancing or inhibiting influence, depending on its state at the moment. (Figure 2). $\mathrm{I}^{-}$participates in the peroxidase reaction according to the well known scheme:

$$
2 \mathrm{I}^{-}+\mathrm{H}_{2} \mathrm{O}_{2} \rightarrow \text { peroxidase } \rightarrow \mathrm{I}_{2}+\mathrm{H}_{2} \mathrm{O}
$$

Peroxidases are a group of nearly ubiquitous enzymes which, on the one hand, catalyze the oxidation of organic and inorganic substrates and, on the other hand, simultaneously reduce noxious (hydro-) peroxides to harmless alcohols or water [6].

Iodide can also inhibit the oxidation of sulfhydryl groups in enzymes or other proteins, according to:

$$
2 \mathrm{RSH} \stackrel{\mathrm{I}^{-} \text {(red.) }}{\longleftarrow} \mathrm{RSSR}+2 \mathrm{H}^{+}
$$

This reaction was proposed by Gauri [7] for the case of disulfide cross-linking of eye lens proteins.

\section{In Vitro Findings}

To prove the antioxidant effect of iodide we used an in vitro model with hyaluronic acid and UV-light as radical producer. It could be shown that iodide inhibits the free radical-induced depolymerisation of hyaluronic acid measured by its decrease of in viscosity. This antiradical effect has been shown significantly down to concentrations 


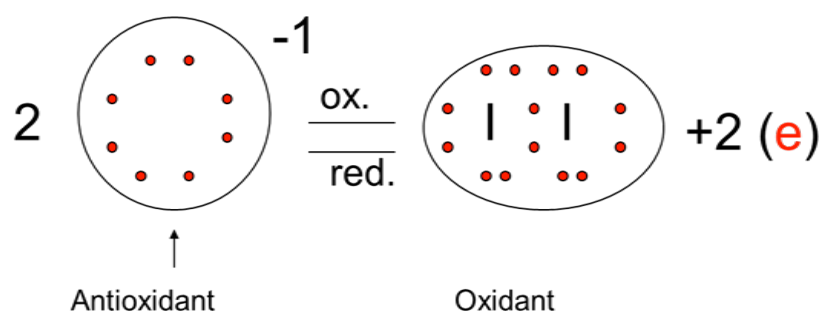

Figure 1. Iodide as electron donor and antioxidant. The red points represent the electrons in the outer shell of the anion or molecule.

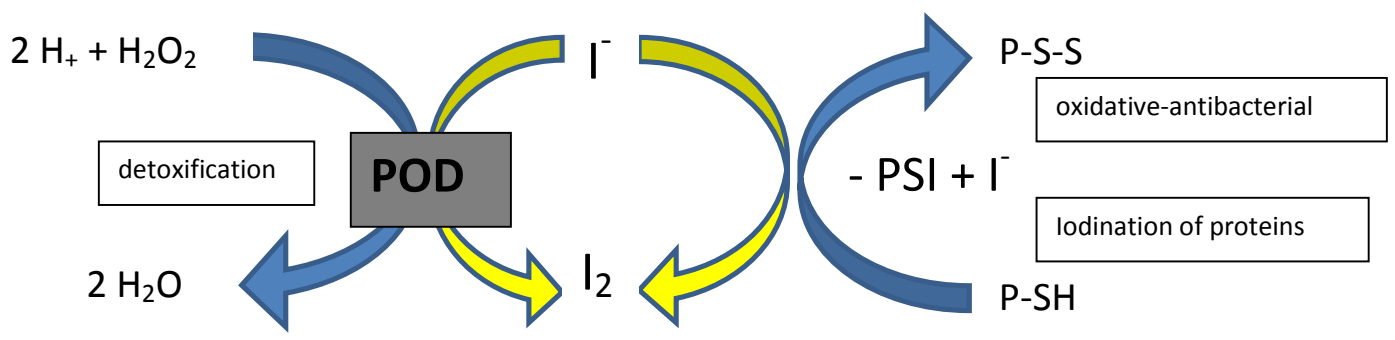

Figure 2. Iodine as cofactor in peroxidase reactions (according to Thomas and Aune [6]). P-S-S = protein disulphide, $\mathrm{PSI}=$ iodinated protein, $\mathrm{PSH}=$ protein with $\mathrm{SH}$-group.

of $3 \mu \mathrm{M}[8]$.

In vitro studies with human serum showed an increase in the total antioxidant status (TAS) by a colorimetric method at a concentration beginning with $0.7 \mu \mathrm{M}$ iodide [9], as well as an increase in peroxidase activity [10]. Accordingly, there was a decrease in the peroxide level in this concentration range (Figure 3). These are relevant serum iodide concentrations that could also be obtained in vivo by supplying iodide in balneotherapeutic applications.

\section{In Vivo Effects and Role in Some "Free Radical Diseases"}

Oxidative stress plays a role in life in general, but especially in the origin and progression of many diseases. With regard to the antioxidative property of iodine (especially $\mathrm{I}^{-}$alone or in iodine-containing waters as used in balneotherapeutic applications in Bad Hall, Austria), the following results should be noted:

- a significant decrease in the malondialdehyde (MDA) level after a 3-week cure [11] [12].

- an increase in the enzyme activities of plasma catalase and glutathione peroxidase in spa patients with diabetes II after a single treatment with iodine brine ([13]; Table 2).

Further investigations on single treatments have shown a favourable effect on the oxidative stress load, measured by peroxides and antioxidative capacity (water- and lipid-soluble fraction) in the blood serum [14]-[16].

Similar results were found by a determination of the TAS in the lacrimal fluid. This indicates an improvement in the defensive capacity of the tear film against oxidative stress. More details will be discussed in the section on eye diseases.

Elemental iodine $\left(\mathrm{I}_{2}\right)$ is an efficient oxidant as seen in its antiseptic and bactericidal effect. It was used empirically in antiquity when wounds were treated with marine sponges that contained iodine (as a review: [17]). Under physiological conditions, iodine exerts an indirect antiseptic effect by enhancing peroxidases in the body and so augmenting leukocytic defenses [1]. Iodine has potential for pro-oxidative processes, e.g. via myeloperoxidase reactions that can produce aggressive, but sometimes desirable compounds like HOCl and HOI.

Some controlled studies also plead for an antiproliferative and thereby favourable role of $\mathrm{I}_{2}$ in patients with severe mastalgia [18] and possibly in carcinogenesis as well [19]. Aceves and Anguiano [20] also propose that a supplementation of molecular iodine $\left(\mathrm{I}_{2}\right)$, but not of iodide should be considered as an adjuvant in breast and prostate cancer therapy, based on the following considerations and results: As seen from animal and human studies, the mammary and prostate glands take up iodine in several chemical forms, and iodine itself exerts a potent antioxidant, antiproliferative and apoptic effect in pathologically altered but not in healthy tissue. The antiproliferative effect of iodine might be mediated by the formation of special iodolipids, called iodolactones, 


\section{Peroxide in the serum}

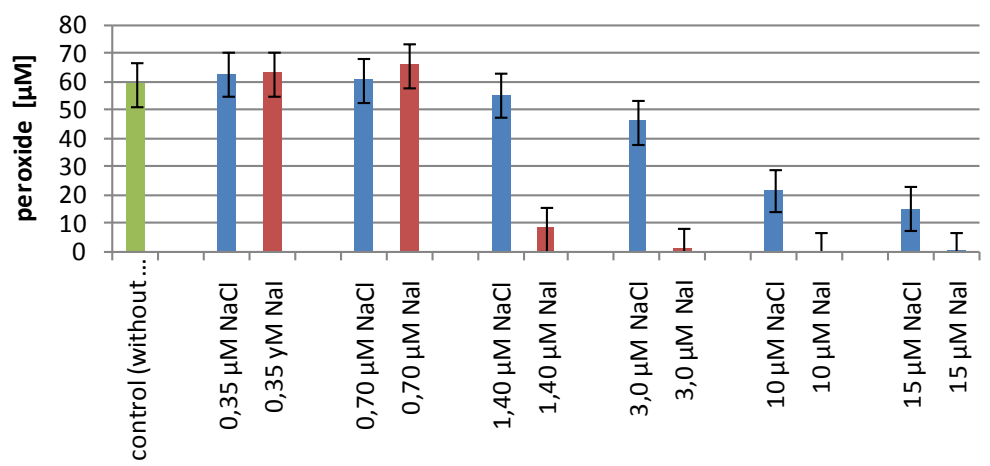

Final concentration of salt supplementation im human sera $[\mu \mathrm{M}]$

Figure 3. Peroxide in the human serum in the presence of $\mathrm{NaI}$ and $\mathrm{NaCl}$; means \pm SEM according to Tatzber et al., 2003 [10].

Table 2. Antioxidant effect of iodide [13] in spa patients with diabetes II.

\begin{tabular}{ccccc}
\hline & \multicolumn{2}{c}{ with iodine brine } & \multicolumn{2}{c}{ with sodium chloride } \\
\hline & before & after & before & after \\
\hline SOD $(\mathbf{\mu g} / \mathbf{g})$ & $3.0 \pm 0.5$ & $2.3 \pm 0.5^{*}$ & $3.6 \pm 0.8$ & $2.7 \pm 0.7^{*}$ \\
Catalase (Act./ml) & $1.1 \pm 0.1$ & $1.4 \pm 0.1^{* *}$ & $1.3 \pm 0.1$ & $1.2 \pm 0.3$ \\
Plasma GSH-PX (U/l) & $201.6 \pm 8.5$ & $213.3 \pm 11.5^{* *}$ & $201.1 \pm 10.8$ & $198.2 \pm 8.3$ \\
Erythrocytes GSH-PX (U/g Hb) & $49.1 \pm 2.3$ & $47.8 \pm 2.4$ & $44.9 \pm 2.5$ & $44.1 \pm 1.8$ \\
Malondialdehyde ( $\mathbf{\mu M / m l )}$ & $15.3 \pm 0.8$ & $15.8 \pm 1.0$ & $14.2 \pm 0.8$ & $14.1 \pm 0.7$ \\
\hline
\end{tabular}

Abbreviations: SOD = superoxide dismutase, GSH-PX = Glutathione peroxidase, Means \pm SEM, ${ }^{*} \mathrm{p}<0.05,{ }^{* *} \mathrm{p}<0.025$, each compared with initial value.

which may also play a role in the control of neoplastic growth, possibly to some extent as inducers through the PPAR (peroxisome proliferator-activated receptor).

\section{Role of Iodine in Some other Diseases Mainly Mediated by Free Radical}

A considerable number of diseases are partially caused or exacerbated by the action of free radicals and subsequent reactions. In general these are predominantly degenerative, chronic and inflammatory disorders mainly associated with aging: cardiovascular diseases, lipid disorders, atherosclerosis (which can be seen as an inflammatory process), diabetes, diseases of the respiratory system, some eye diseases (cataract, dry eye syndrome, macula degeneration), neurological defects, degenerative joint diseases and general stress.

In some diseases iodine can be effective indirectly via thyroid function as well as via non-endocrine mechanisms. In both cases, pro- and antioxidative effects can play a role. With regard to thyroid function, both hypoand hyperthyroid states can influence the antioxidant status [21]: Kanno et al. [22] have shown that both iodine deficiency as well as iodine excess could promote tumours in rat thyroids.

In contrast, positive correlations have been found between TSH (thyroid stimulating hormone), triiodothyronine (T3) and thyroxine (T4) on the one hand, and the activity of antioxidant enzymes on the other [23] [24]. There are also close connections between iodine and selenium metabolism: It is well known that Se plays an important role in the antioxidant system as an essential element in the defensive enzyme glutathione peroxidase as well as in the selenium-containing enzyme iodothyronine-5'-deiodinase (type 1), which plays an important role in thyroid metabolism. In general, hypothyroidism seems to offer a certain protection against free radical damage, as shown by Paller et al. [25] and Teare et al. [26].

In cardiac and vascular disorders, a normal or slightly elevated thyroid hormone level is favourable in the sense of an antiatherogenic effect: An increase in basal metabolism due to thyroid hormones decreases cholesterol and 
triglyceride levels, and the activity of cholesteryl ester transfer protein is decreased in hypothyroidism [27]. This clearly reflects a close connection between thyroid and lipid metabolism.

Iodine supplied in balneotherapeutic doses $(10 \mathrm{mg} /$ day) usually causes a slight, transient inhibition of thyroid function (known as the Wolff-Chaikoff-Effect) that can decrease hyper-adrenergic reactions [28] and consequently relax the vascular system and reduce pro-oxidative stress by decreasing radical production.

But there are still many open questions on the effect of balneotherapeutic treatments on pro-/antioxidative systems.

Some results of our working group also support the view that iodine has an antiatherogenic effect (see also section 7) via stimulation of peroxidase activity to decrease peroxides [10] and MDA [11]. It was also shown that single treatments with iodine brine indicate a favourable effect on the pro-/antioxidative balance [14] [15], which in turn and together with exercise could decrease risk factors for vascular disease.

A recent paper [29] gives evidence of an acute therapeutic role for iodide in ischemia reperfusion injury: Infusion of iodide (but not the oxidized form iodate) reduces heart damage by $75 \%$ when delivered intravenously following temporary loss of blood flow prior to perfusion of the heart in a mouse model of acute myocardial infarction. Normal thyroid function may be required for this interesting positive effect of iodide. The mechanism of this action is not clear, but could be related to a special antioxidative or reducing effect of iodide.

Iodine may affect atherosclerotic processes on several levels:

1) via (direct) antioxidative effects on lipids and lipoproteins and unsaturated fatty acids, resulting in a downregulation of atherogenic, oxidatively modified LDL-fractions

2) indirectly via increasing the activity of antioxidant enzymes (e.g. GSH-peroxidase)

3) indirectly via thyroid function and

4) via further mechanisms, e.g. by effects on connective tissue metabolism, which is also influenced by oxidative stress.

A particular role is also ascribed to iodine in respiratory diseases. Iodide not only lowers viscosity but also acts directly or indirectly via peroxidase systems as a disinfectant and has positive effects on the immunological system. Reactive oxygen species (ROS) are very important in inflammatory diseases of the respiratory tract (increased production in asthma, induction of the "oxygen burst" with all its consequences). Treatment with iodide and other antioxidants could be useful in this context.A clinically relevant study [30] shows that the lactoperoxidase $/ \mathrm{I}^{-} / \mathrm{H}_{2} \mathrm{O}_{2}$ system (see also section 5) can contribute significantly to airway antiviral defenses. Furthermore, the delivery of $\mathrm{I}^{-}$to airway mucosa may augment innate antiviral immunity. It is interesting that these antiviral activities were not seen when the alternative anion $\mathrm{SCN}^{-}$(which is also a substrate of lactoperoxidase) was substituted for $\mathrm{I}^{-}$. This specific effect of iodide can be seen as a new approach to preventing or treating viral respiratory infections.

There are further diseases that may be influenced by the action of free radicals and so could be favourably influenced by iodine, including degenerative alterations of the supporting tissue and some inflammatory skin diseases. According to Sterling and Heymann [31] oral potassium iodide is useful for inflammatory dermatoses like erythema nodosum, subacute nodular migratory panniculitis and erythema multiforme. KI is also successfully used for cutaneous and lymphocutaneous sporotrichosis. Though the precise mechanism by which KI acts is unknown, iodine/iodide could exert an antimicrobial effect via the pro-/antioxidative system.

\section{Eye Diseases}

Iodine has some interesting applications in disorders of the eye. Iodide has been reported to have positive effects on the electroretinogramm [32] and on visual acuity with macular degeneration [33], myopia, and colour perception [34] [35], perhaps due to better microcirculation.

In connection with the antioxidative properties of iodide and its function as a free radical scavenger, the following concepts and findings may be important: In normal cases the eye structures are very well supplied with antioxidative defense mechanisms, including SOD, peroxidases, catalase, GSH and protective vitamins (C, E, carotinoids, etc.). Under pathologic conditions and in advanced age these important defense mechanisms no longer suffice to protect the eye from increased radical influences (caused by light and other radiation) and, in consequence, from tissue and enzyme damage. This damage in turn can induce degenerative diseases such as cataract and macular degeneration. On the basis of these considerations and the many positive experiences with (balneo-) therapeutic treatments of eye diseases, since the middle of the last century the Paracelsus Institute of 
Bad Hall has studied these effects systematically and experimentally in order to provide a scientific basis for the indications for iodine in the treatment of eye disorders.

In spite of somewhat contradictory results, iodides have been repeatedly recommended and used to treat cataracts. Cataract is due to protein cross-linking via sulfhydryl oxidation and protein glycation, whereby oxygen is involved in most cases, including photodynamic reactions. Compounds such as riboflavin or tryptophan derivatives absorb light. The energy is transferred to molecular oxygen, yielding the highly reactive singlet oxygen $\left({ }^{1} \mathrm{O}_{2}\right)$ which in turn can react with unsaturated fatty acids and so form destructive peroxides. In this oxidative reaction pathway, reductive or antioxidant electron donors like iodide can act as inhibitors. As shown by Hippeli et al. [36] in an in vitro model, potassium iodide (KI) at $\mathrm{mM}$ concentrations prevented the photodynamic formation of high molecular weight aggregates, as found in the late processes of cataract formation, demonstrating KI as a potential anticataract agent. An experimental study by our working group [37] with an Emory mouse model for age-onset cataracts showed that a long-term daily supply of $256 \mu \mathrm{g} \mathrm{I} / \mathrm{kg}$ body weight with the drinking water delayed cataract formation by about 4 - 6 weeks, corresponding to 5 - 10 years in humans. These findings were explained by the protective effect of iodide on the oxidative alterations in the lens during cataractogenesis, especially the formation of S-S bonds.

Another indication for iodine-containing remedies that has been investigated intensively at the Paracelsus Institute is the dry eye syndrome, a disturbance of the lacrimal film that is seen increasingly frequently. The components of the lacrimal fluid (proteins, hyaluronate, lipids) are destroyed (depolymerized) by ozone, UV light, cigarette smoke and other pro-oxidant agents, exhausting the natural antioxidative capacity. This defensive capacity against free radicals and similar pro-oxidative substances (e.g. $\mathrm{H}_{2} \mathrm{O}_{2}$ ) can be improved by addition of antioxidants such as vitamins A, C, E and also iodide to artificial tears or by application of iodine waters [38] [39]. The iodide-iontophoresis treatment as developed and used in Bad Hall is proven supportive therapy for patients with dry eye syndrome. Several studies have shown that effective amounts of iodine can be introduced by iontophoresis into all eye tissues [40] [41], and the antioxidative capacity of the lacrimal fluid increased. This increase is still measurable even 6 to 9 months after treatment [42]. Subjective complaints before and after the iodide treatments were collected from standardized interviews, whereby $93.8 \%$ of the patients indicated an improvement after treatment. This positive effect continued in most cases (47.2\%) up to 6 months, in some cases even more than one year [43].

In patients with Sjögren's syndrome an increase of oxidative stress in the conjunctiva is also responsible for lacrimal dysfunction [44].

Further indications based on the antioxidative or other extrathyroidal effects of iodine include:

- degenerative alterations in the ocular fundus; beginning macular degeneration

- diseases of the optic nerve and degeneration of the retina (e.g. glaucoma)

- vascular diseases of the eye (atherosclerotic alterations)

- cornea diseases and turbidity of the vitreous body

Age-related macular degeneration (AMD), the leading cause of blindness in the developed world, can also be seen partly as a consequence of high oxidative stress to the retina because of its constant exposure to light. Furthermore, environmental risk factors such as diet (reduced intake of antioxidant vitamins), smoking, aging, and UV radiation affect the antioxidant status and increase the generation of ROS, leading to oxidative damage in the retina. It so can be assumed that reinforcing the antioxidative system, e.g. by iodide supply, can help defend against ROS.

There is substantial evidence to suggest that oxidative stress also plays a major part in the pathogenesis of glaucoma. Glaucoma is a chronic neurogenerative disease characterized by progressive loss of retinal cells. Excessive intraocular pressure (IOP) compresses the retinal ganglion cell axons and damages them [45], while increased oxidative stress also contributes to the glaucomatous neurodegeneration. This suggests that combined treatment of glaucoma patients with IOP lowering agents and appropriate antioxidants could make sense.

As pro-oxidative mechanisms and ROS play a major role in atherosclerosis (see section 8), they are also important for vascular diseases and atherosclerotic alterations in the eye. Accordingly, antioxidants such as vitamins $\mathrm{C}$ and E, polyphenols, and also iodide could lower the risk of developing oxidative stress-mediated vascular disease in the eye. In addition, oxidative stress can also induce retinal neovascularization and endothelial dysfunction [44] [46].

The cornea is intensely exposed to light and therefore to ROS. Since the corneal tissues have slow turnover rates, harmful compounds resulting from oxidative processes can persist in the corneal tissue for a long time. 
Like the lens and the vitreous body, the cornea is avascular, so that there is little possibility to remove such substances. A supply with suitable antioxidants, iodide included, could be useful in this context. Positive experiences with iodine cures have also been made in turbidities of the vitreous body of the eye, e.g. after bleedings and inflammation. In these cases resorption may be promoted by iodine [47].

\section{Possible Side Effects}

Some biochemical reactions involving iodine can have undesirable effects. Enhanced peroxidase activity could be connected with undesired increased formation of aggressive hypo-halide acids (HOI, HOCl), which are antimicrobial but damage epithelial tissue. Excessive doses of iodine or iodide (grams) can not only disrupt thyroid function (Wolff-Chaikoff effect, hypo- as well as hyperthyroidism) but also can damage the liver and kidneys, perhaps by oxidative reactions mediated by iodine. A rare but possible side effect of iodine uptake at balneotherapeutic doses can be the "iodism", an individual iodine hypersensitivity with headache, conjunctivitis, swelling of the salivary glands, fever and skin reactions.

Hypothyroidism (Grave's disease) and other thyroid conditions are specific contraindications for iodine/iodide treatment. Hypothyroidism caused by Hashimoto disease may be also a contraindication, especially for higher doses.

\section{Conclusion}

Outgoing from physico-chemical data ( $\mathrm{I}^{-}$as electron donor and co-factor of peroxidase reactions) and from the iodine uptake and distribution in the human body, in vitro as well as in vivo effects of iodide were presented. The data argue for a predominantly antioxidant activity of iodide and of iodine/iodide-containing waters. These properties of iodide are supposed to play an important role general in life and especially in the origin and in the propagation of many diseases in which oxidative stress and free radicals are causally involved, as there are: cardio-vascular diseases, respiratory disorders, inflammatory skin diseases and especially degenerative eye diseases (cataract, beginning macular degeneration, dry eye syndrome). These diseases are also well treated by balneotherapy with iodine-containing waters. Molecular iodine itself $\left(\mathrm{I}_{2}\right)$ can act as oxidant what could be responsible for its antiseptic and bactericidal effect. In several cases (e.g. cancer) the mechanism of the I-effect is not fully understood. In discussion there are indirect effects via thyroid function or other iodine compounds (iodolactons). The members of the Paracelsus Society of Bad Hall are convinced that the extrathyroidal actions of iodine/iodide might be still an important field for investigation.

\section{References}

[1] Stolc, V. (1972) Regulation of Iodine Metabolism in Human Leukocytes by Adesonine 3',5'-Monophosphate. Biochimica et Biophysica Acta, 264, 285-288. http://dx.doi.org/10.1016/0304-4165(72)90292-9

[2] Klein, E. (1960) Der endogene Haushalt des Menschen und seine Störungen. Georg Thieme Verlag Stuttgart, 1.

[3] Winkler, R. (1972) Jodverteilung in der bilateral nephrektomierten Ratte unter drei verschiedenen experimentellen Bedingungen. Österr Ärztezeitg, 27, 527.

[4] Winkler, R. and Moser, M. (1987) Neuere Aspekte über die Wirksamkeit des extrathyreoidalen Jods. Balneologische Bioklimatologische Mitteilungen, 27, 3-14.

[5] Klieber, M., Winkler, R. and Srirajaskanthan, R. (2009) Iodine Mineral Water and Its Therapeutic Use in Health Resorts: Iodine Consumption from Natural Mineral Waters and Its Effect on the Body. In: Preedy, V.R., Ed., Comprehensive Handbook of Iodine, Academic Press, San Diego, 339-344.

[6] Thomas, E.L. and Aune, T.M. (1978) Cofactor Role of Iodide in Peroxidase Antimicrobial Action against Escherichia coli. Antimicr Agents and Chemotherapie, 13, 1000-1005. http://dx.doi.org/10.1128/AAC.13.6.1000

[7] Gauri, K. (1979) Bioverfügbarkeit von ${ }^{125}$ Jod im Auge nach Einträufelung von Kaliumjodidlösung. Der Augenspiegel, 2 .

[8] Winkler, R., Moser, M. and Buchberger, W. (1989) Die Wirksamkeit von Jodid als Sauerstoffradikalfänger. Wissenschaftliche Zeitung der Humboldt Universität zu Berlin Reihe Medizin, 38, 69-76.

[9] Winkler, R., Griebenow, S. and Wonisch, W. (2000) Effect of Iodide on Total Antioxidant Status of Human Serum. Cell Biochemistry and Function, 18, 143-146. http://dx.doi.org/10.1002/(SICI)1099-0844(200006)18:2<143::AID-CBF857>3.0.CO;2-\# 
[10] Tatzber, F., Griebenow, S., Wonisch, W. and Winkler, R. (2003) Dual Method for the Determination of Peroxidase Activity and Total Peroxides-Iodide Leads to a Significant Increase of Peroxidase Activity in Human Sera. Analytical Biochemistry, 316, 147-153. http://dx.doi.org/10.1016/S0003-2697(02)00652-8

[11] Winkler, R. (1996) Balneotherapeutische Maßnahmen gegen die Folgen von Sauerstoffstress. Vitaminspur, 11, 19-29.

[12] Feyertag, J., Scheidleder, B., Ekmekcioglu, C., Marktl, W. and Winkler, R. (1997) Einfluss einer Jodgabe auf die Lipidperoxidation von Kurpatienten. Physikalische Medizin, Rehabilitationsmedizin, Kurortmedizin, 7, $269-271$. http://dx.doi.org/10.1055/s-2008-1061886

[13] Moser, M., Buchberger, W., Mayer, H. and Winkler, R. (1991) Einfluß einer Jodtrinkkur auf den antioxidativen Status von Diabetikern. Wiener Klinische Wochenschrift, 103, 183-186.

[14] Loos, W., Griebenow, S., Winkler, R. and Porta, S. (2006) Kureinzelbehandlungen beeinflussen pro/antioxidatives Gleichgewicht. Physikalische Medizin, Rehabilitationsmedizin, Kurortmedizin, 16, 326-329. http://dx.doi.org/10.1055/s-2006-940200

[15] Loos, W., Griebenow, S., Winkler, R. and Porta, S. (2007) Können Kurbehandlungen zur Stressverarbeitung beitragen? Physikalische Medizin, Rehabilitationsmedizin, Kurortmedizin, 17, 108-111. http://dx.doi.org/10.1055/s-2007-940104

[16] Bender, T., Barisk, A.J., Vaghy, R., Gomez, R. and Kovacs, I. (2007) Effect of Balneotherapy on the Antioxidant System. A Controlled Pilot Study. Archives of Medical Research, 38, 86-89. http://dx.doi.org/10.1016/j.arcmed.2006.08.007

[17] Venturi, S., Donati, F.M., Venturi, A., Venturi, M., Grossi, L. and Guidi, A. (2000) Role of Iodine in Evolution and Carcinogenesis of Thyroid, Breast and Stomach. Advances in Clinical Pathology, 4, 11-17.

[18] Kessler, J. (2009) Are There Side Effects When Using Supraphysiologic Levels of Iodine Treatment Regiments? In: Preedy, V.R., Burrow, G.N. and Watson, R.R., Eds., Comprehensive Handbook of Iodine: Nutritional, Endocrine and Pathological Aspects, Academic Press, San Diego, 801-810. http://dx.doi.org/10.1016/B978-0-12-374135-6.00082-0

[19] Garcia-Solis, P., Alfaro, Y., Anguiano, B., Delgado, G., Guzman, R.C., Nandi, S., Diaz-Munoz, M., Vazquez-Martinez, O. and Aceves, C. (2005) Inhibition of $N$-Methyl- $N$-Nitrosourea-Induced Mammary Carcinogenesis by Molecular Iodine $\left(\mathrm{I}_{2}\right)$ but Not by Iodide $\left(\mathrm{I}^{-}\right)$Treatment Evidence That $\mathrm{I}_{2}$ Prevents Cancer Promotion. Molecular and Cellular Endocrinology, 236, 49-57. http://dx.doi.org/10.1016/j.mce.2005.03.001

[20] Aceves, C. and Anguiano, B. (2009) Is Iodine an Antioxidant and Antiproliferative Agent for the Mammary and Prostate Glands? In: Preedy, V.R., Burrow, G.N. and Watson, R.R., Eds., Comprehensive Handbook of Iodine: Nutritional, Endocrine and Pathological Aspects, Academic Press, San Diego, 249-257.

[21] Resch, U., Helsel, G., Tatzber, F. and Sinzinger, H. (2002) Antioxidant Status in Thyroid Dysfunction. Clinical Chemistry and Laboratory Medicine, 40, 1132-1134. http://dx.doi.org/10.1515/cclm.2002.198

[22] Kanno, J., Onodera, H., Furut, A.K., Maekawa, A., Kasuga, T. and Hayashi, Y. (1992) Tumor-Promoting Effects of Both Iodine Deficiency and Iodine Excess in the Rat Thyroid. Toxicology Pathology, 20, 226-235. http://dx.doi.org/10.1177/019262339202000209

[23] Kurasaki, M., Saito, T., Kaji, H., Kojim, A.Y. and Saito, K. (1986) Increased Erythrocyte Catalase Activity in Patients with Hyperthyroidism. Hormone and Metabolic Research, 18, 56-59. http://dx.doi.org/10.1055/s-2007-1012225

[24] Bolzan, A.D., Brown, O.A., Goya, R.G. and Bianchi, M.S. (1995) Hormonal Modulation of Antioxidant Enzyme Activities in Young and Old Rats. Experimental Gerontology, 30, 169-175. http://dx.doi.org/10.1016/0531-5565(94)00053-0

[25] Paller, M.S. and Sikora, J.J. (1986) Hypothyroidism Protects against Free Radical Damage in Ischemic Acute Renal Failure. Kidney International, 29, 1162-1166. http://dx.doi.org/10.1038/ki.1986.122

[26] Teare, J.P., Greenfield, S.M., Marway, J.S., Preedy, V.R., Punchard, N.A., Peters, T.J. and Thompson, R.P.H. (1993) Effect of Thyroidectomy and Adrenalectomy in Liver Glutathione and Malondialdehyde Levels after Acute Ethanol Injection. Free Radical Biology and Medicine, 14, 655-660. http://dx.doi.org/10.1016/0891-5849(93)90147-M

[27] Dullaart, R.P.F., Hoogenberg, K., Groener, J.E.M., Dikkeschei, L.D., Erkelens, D.W. and Doorenbos, H. (1990) The Activity of Cholesteryl Ester Transfer Protein Is Decreased in Hypothyroidism: A Possible Contribution to Alterations in High-Density Lipoproteins. European Journal of Clinical Investigation, 20, 581-587. http://dx.doi.org/10.1111/j.1365-2362.1990.tb01904.x

[28] Levey, G.S. and Klein, I. (1990) Catecholamine-Thyroid Hormone Interactions and the Cardiovascular Manifestations of Hyperthyroidism. The American Journal of Medicine, 88, 642-646. http://dx.doi.org/10.1016/0002-9343(90)90533-J

[29] Iwata, A., Morrison, M.L. and Roth, M.R. (2014) Iodide Protects Heart Tissue from Reperfusion Injury. PLoS ONE, 9, e112458. http://dx.doi.org/10.1371/journal.pone.0112458

[30] Fischer, A.J., Lennemann, N.J., Krishnnamurthy, S., Pocza, P., Kurairaj, L., Launspach, J.L., Rhein, B.A., WohlfordLenane, C., Lorentzen, D., Banfi, B. and McCray, P.B. (2011) Enhancement of Respiratory Mucosal Antiviral De- 
fenses by the Oxidation of Iodide. American Journal of Respiratory Cell and Molecular Biology, 45, 874-881. http://dx.doi.org/10.1165/rcmb.2010-0329OC

[31] Sterling, J.B. and Heymann, W.R. (2000) Potassium Iodide in Dermatology: A 19th Century Drug for the 21st Century? Uses, Pharmacology, Adverse Effects, and Contraindications. Journal of the American Academy of Dermatology, 43, 691-697. http://dx.doi.org/10.1067/mjd.2000.107247

[32] Hellauer, H. (1972) Effect of Iodine in an ERG-Study on the Isolated Frog Retina. Klinische Monatsblätter für Augenheilkunde, 161, 63-66.

[33] Rieger, R.G. (1973) Änderung der Sehschärfe bei Patienten mit Sklerose der Retinalgefäße und degenerativen Veränderungen der Maculalutea während des Kuraufenthaltes in Bad Hall. In: Berichte über die 73. Zusammenkunft der Deutschen Ophthalmologische Gesellschaftin Heidelberg 1973, München, 197.

[34] Rieger, G. (1979) Änderung der Sehschärfe bei Patienten mit höhergradiger Myopie während ihres Kuraufenthaltes in Bad Hall/Oberösterreich. Klinische Monatsblätter für Augenheilkunde, 173, 103-106.

[35] Rieger, G. (1988) Der Einfluss von kombinierten Jodkurbehandlungen in Bad Hall auf die Farbwahrnehmung von Patienten. Klinische Monatsblätter für Augenheilkunde, 93, 416-419.

[36] Hippel, I.S., Schempp, H. and Elstner, F.F. (2008) Oxidative Stress and Cataract. In: Zierhut, M., Cadenas, E. and Rao, N.A., Eds., Free Radicals in Ophthalmic Disorders, CRC Press, Boca Raton, 81-105. http://dx.doi.org/10.3109/9781420044348-8

[37] Buchberger, W., Winkler, R. and Moser, M. (1991) Influence of Iodide on Cataractogenesis in Emory Mice. Ophthalmic Research, 23, 303-330. http://dx.doi.org/10.1159/000267127

[38] Rieger, R.G., Griebenow, S., Winkler, R. and Stoiser, E. (2000) Der antioxidative Status der Tränenflüssigkeit vor und nach kombinierten Kurbehandlungen in Bad Hall. Spektrum der Augenheilkunde, 14, 319-324. http://dx.doi.org/10.1007/BF03162846

[39] Griebenow, S., Rieger, G. and Horvath-Winter, J. (2003) Eine neue Methode zur Bestimmung der antioxidativen Kapazität der Tränenflüssigkeit. Spektrum der Augenheilkunde, 17, 227-230. http://dx.doi.org/10.1007/BF03164397

[40] Hagmüller, R.K. and Trichtel, F. (1960) Autoradiographische Studien zur Jodanreicherung im Auge durch Iontophorese. Ophthalmologica, 140, 44-45. http://dx.doi.org/10.1159/000303810

[41] Rieger, G., Winkler, R., Buchberger, W. and Moser, M. (1995) Iodine Distribution in a Porcine Eye Model Following Iontophoresis. Ophthalmologica, 209, 84-87. http://dx.doi.org/10.1159/000310586

[42] Rieger, G. (2001) Glaukom und Augenbehandlungen in Bad Hall—Eine retrospektive Studie. Spektrum der Augenheilkunde, 15, 150-153. http://dx.doi.org/10.1007/BF03162872

[43] Rieger, G., Winkler, R., Stoiser, E. and Landerl, J. (1997) Zur subjektiven Befindlichkeit von Patienten mit Beschwerden des "trockenen Auges" vor und nach Absolvierung von Jodkurbehandlungen in Bad Hall. Spektrum der Augenheilkunde, 11, 66-71. http://dx.doi.org/10.1007/BF03164101

[44] Uchino, Y., Kawakita, T., Ishi, N. and Tsubota, K. (2012) A New Mouse Model of Dry Eye Disease. Oxidative Stress Affects Functional Decline in the Lacrimal Gland. Cornea, 31, 63-67. http://dx.doi.org/10.1097/ICO.0b013e31826a5de1

[45] Osborne, N.N. (2008) Involvement of Oxidative Stress in the Pathogenesis of Glaucoma. In: Zierhut, M., Cadenas, E. and Rao, N.A., Eds., Free Radicals in Ophthalmic Disorders, CRC Press, Boca Raton, 71-79. http://dx.doi.org/10.3109/9781420044348-7

[46] Pemp, B., Polska, E., Karl, K., Last, A.M., Minichmayr, A., Garhofer, G., Wolzl, M. and Schmetterer, L. (2010) Effects of Antioxidants (AREDS Medication) on Ocular Blood Flow and Endothelial Function in an Endotoxin-Induced Model of Oxidative Stress in Humans. Investigative Opthalmology \& Visual Science, 51, 2-6. http://dx.doi.org/10.1167/iovs.09-3888

[47] Rieger, G. (2011) Jodkurbehandlungen bei Augenleiden. In: Foiser, W., Ed., Buchbeitrag in: Integrative Kurmedizin, Verlagshaus der Ärzte, Hsg, 397-416. 